\title{
Book Notice
}

La nécessité de Claude Bernard, Actes du Colloque de Saint-Julien-en-Beaujolais des 8, 9 \& 10 décembre 1989, sous la direction de Jacques Michel, Paris, Méridiens Klincksieck, 1991, pp. xi, 317 (2-86563-295-4).

This book comprises the proceedings of a three-day meeting held in 1989 to discuss the contemporary relevance of Claude Bernard's work. Under the patronage of the Fondation Marcel Mérieux and the Musée Claude Bernard of Saint-Julien-en-Beaujolais, seventeen scholars (historians, sociologists, philosophers, medical researchers and biologists) reviewed and debated some of the key contributions of the master physiologist to science. As is often the case in this type of publication, the worth of some of the papers is questionable. The most interesting and scholarly presentations were those of Christiane Sinding and Frederic L. Holmes on Bernard's construct of milieu intérieur, and Mirko D. Grmek's splendid paper on Bernard's conception of life and how it shared features of both materialism and vitalism. Jean Gayon's paper on the minor place of heredity in the Bernardian corpus, and Jacques Michel's views on the physiologist's influence on the genesis and structure of Emile Durkheim's sociology also stand out for their originality. Though this collection is of mixed quality, it does provide a general overview of French academia's present interest in Claude Bernard and his work. Furthermore, its reading is made more interesting by the appendage of a summary of the six debates which followed each session, a valuable initiative which should be encouraged.

\section{BOOKS ALSO RECEIVED}

(The inclusion of a title does not preclude the possibility of subsequent review. Items received, other than those assigned for review, are ultimately incorporated into the collection of the Wellcome Institute for the History of Medicine.)

Bibliography of the history of medicine, National Library of Medicine, no. 27, Bethesda, MD, US Department of Health and Human Sciences, 1991, pp. ix, 362, \$23.75 worldwide, $\$ 19.00$ (USA) (0-16-038049-9)

ROBERT H. BLANK, Regulating reproduction, New York, Columbia University Press, 1992, pp. xii, 272, \$17.00 (paperback 0-231-07016-0). First published in hardback in 1990.

DAVID N. LIVINGSTONE, The preadamite theory and the marriage of science and religion, Transactions of the American Philosophical Society, vol. 32, pt 3, Philadelphia, American Philosophical Society, 1992, pp. x, 81, illus., \$16.00 (0-87169-823-4).

BERND LORENZ, Allgemeinbildung und Fachwissen: Deutsche Ärzte und ihre Privatbibliotheken, Studien zur Medizin-, Kunst- und Literaturgeschichte 30, Herzogenrath, Verlag Murken-Altrogge, 1992, pp. vi, 175 (3-921801-67-2).

JEAN PIROTTE and HENRI DERROITTE (eds), Élises et santé dans le tiers monde hier et aujourd'hui, Studies in Christian mission, Leiden, E. J. Brill, 1991, pp. xvii, 176, illus., Gld. 95.00, $\$ 50.00$ (90-04-09470). 